\title{
KARAKTERISTIK GAS HASIL PROSES PIROLISIS LIMBAH PLASTIK POLIETILENA (PE) DENGAN MENGGUNAKAN KATALIS RESIDUE CATALYTIC CRACKING (RCC)
}

\author{
Siti Naimah dan Novi Nur Aidha \\ Balai Besar Kimia dan Kemasan, Kementerian Perindustrian \\ Jl. Balai Kimia I Pekayon, Pasar Rebo, Jakarta Timur \\ E-mail : st.naimah@gmail.com
}

Received : 27 Maret 2017; revised : 29 Maret 2017; accepted : 9 Mei 2017

\begin{abstract}
ABSTRAK
KARAKTERISTIK GAS HASIL PROSES PIROLISIS LIMBAH PLASTIK POLIETILENA (PE) DENGAN MENGGUNAKAN KATALIS RESIDUE CATALYTIC CRACKING (RCC). Penelitian ini bertujuan untuk untuk membandingkan karakteristik gas yang dihasilkan pada proses pirolisis limbah plastik polietilena (PE) dengan variabel konsentrasi menggunaan katalis Residue Catalytic Cracking (RCC). Pada proses ini digunakan reaktor pirolisis kapasitas $5 \mathrm{~kg}$ dan ditambahkan katalis $R C C$ sebagai variabel penelitian. Gas yang terbentuk ditampung dalam gas sampler dan diukur flowrate. Karakteristik gas yang dihasilkan dikarakterisasi dengan menggunakan GC System. Variabel konsentrasi katalis yang digunakan pada penelitian ini adalah 7,5\%, 10\%, 12,5\%, 15\%, dan $17,5 \%$ dari bahan baku. Penambahan konsentrasi katalis sebesar $10 \%$ dari bahan baku menghasilkan campuran propana dan butana sebesar $35,657 \%$, etana $12,13 \%$, dan pentana $5,221 \%$. Disamping itu pada penggunaan konsentrasi katalis $10 \%$, gas pengotor yang dihasilkan yaitu gas $\mathrm{CO}$ dan $\mathrm{CO}_{2}$ rendah yaitu sebesar $0 \%$ dan $0,193 \%$. Pengukuran flowrate gas yang dihasilkan menunjukkan bahwa semakin besar konsentrasi katalis, maka waktu proses yang dibutuhkan untuk mendapatkan gas semakin cepat.
\end{abstract}

Kata kunci : $R C C$, Katalis, Pirolisis, Gas

\begin{abstract}
CHARACTERISTICS GAS FROM PYROLYSIS PLASTIC POLYETHYLENE (PE) WASTE PROCESS USING RESIDUE CATALYTIC CRACKING (RCC). This study aims to compare the characteristics of gases produced in the pyrolysis process of polyethylene plastic waste (PE) under different concentration of residue catalytic cracking (RCC). In the process, the pyrolysis reactor was with a capacity of $5 \mathrm{~kg}$ added with RCC catalyst as a variable. The formed gases were collected in a sampler gas and flowrate was measured. The characteristics of the resulting gas were characterized using GC System. The catalyst concentration variables were $7.5 \%, 10 \%$, $12.5 \%, 15 \%$ and $17.5 \%$ of the raw materials. The addition of catalyst concentration of $10 \%$ from the raw material resulted in a mixture of propane and butane $35.657 \%$, ethane $12.13 \%$ and pentane $5.221 \%$. In addition, the use of $10 \%$ catalyst concentration resulted in low impurity of gas $\mathrm{CO}$ of $0 \%$ and $\mathrm{CO}_{2}$ of $0.193 \%$ respectively. The measurement of gas flowrate showed that the higher catalyst concentration the faster the process to produce the gas.
\end{abstract}

Key words : RCC, Catalysts, Pyrolysis, Gas

\section{PENDAHULUAN}

Indonesia seperti negara berkembang lainnya, mengalami peningkatan konsumsi plastik karena perkembangan ekonomi dan pesatnya urbanisasi. Pada tahun 2010, Indonesia mengonsumsi $10 \mathrm{~kg}$ plastik per kapita per tahun (Syamsiro et al. 2014). Oleh karena itu, diperlukannya penanggulangan plastik bekas pakai. Plastik PE adalah hidrokarbon rantai lurus/tidak bercabang yang berasal dari olefin yaitu senyawa tak jenuh dengan rumus bangun
$\mathrm{CnH}_{2 \mathrm{n}}$. Perengkahan hidrokarbon tanpa katalis menggunakan suhu dan tekanan yang tinggi disebut dengan dekomposisi termal. Sedangkan yang menggunakan katalis disebut perengkahan katalitis (Syamsiro et al. 2014). Perengkahan olefin menjadi senyawa yang berakhiran-ene seperti ethene (ethylene) dan propena (propylene). Olefin tidak stabil dapat bereaksi dengan oksigen dan bromium (Sadeghbeigi 2012). Perengkahan sampah plastik dengan 
proses pirolisis adalah mengkonversi sampah plastik menjadi bahan petrokimia dasar yang dapat digunakan menjadi bahan baku hidrokarbon atau bahan bakar. Proses pirolisis untuk mengkonversi limbah plastik menjadi suatu produk telah dilakukan penelitian pada suhu rendah sampai dengan suhu tinggi, $25^{\circ} \mathrm{C}$ sampai dengan $140{ }^{\circ} \mathrm{C}, 50{ }^{\circ} \mathrm{C}$ sampai dengan $250{ }^{\circ} \mathrm{C}$ dan $300{ }^{\circ} \mathrm{C}$ sampai dengan $550{ }^{\circ} \mathrm{C}$ dilakukan oleh Ademiluyi and Adebayo (2007). Teknologi pirolisis dengan memanaskan plastik High Density Polyethylene (HDPE) pada suhu $420{ }^{\circ} \mathrm{C}$ sampai dengan $440{ }^{\circ} \mathrm{C}$ tanpa adanya oksigen telah dilakukan oleh Sharma et al. (2014). Sedangkan penelitian pengukuran pendistribusian panas pada suhu reaktor silender $450^{\circ} \mathrm{C}$ dalam pirolisis botol plastik telah dilakukan oleh Hartulistiyosoto et al. (2015).

Keuntungan dari proses pirolisis adalah mengurangi volume limbah plastik di lingkungan, menghasilkan fraksi cair, padat, dan gas yang dapat digunakan sebagai bahan bakar dan bahan kimia (chemical feed stock), sehingga mengurangi masalah lingkungan. Proses pirolisis dapat dilakukan dengan dan tanpa katalis. Keuntungan pada pirolisis dengan katalis yaitu katalis menurunkan fraksi cair dan meningkatkan fraksi gas. Katalis yang pada proses pirolisis berfungsi untuk menurunkan temperatur reaksi, mempercepat reaksi, serta menghasilkan produk dengan karbon atom yang lebih spesifik dan hidrokarbon yang ringan (Patni et al. 2013; Ćwik 2014).

Beberapa macam katalis telah digunakan dalam proses pirolisis seperti katalis dari bahan alam (silika alumina, bentonit clay, alumina hidroksilat, zeolit) dan katalis sintetik (metallic oxides, silika alumina, silika magnesia, karbon aktif (Almeida dan Marque 2015; Kyaw dan Hmwe 2015). Industri petroleum banyak melakukan pengolahan minyak mentah dengan menggunakan $R C C$, sehingga pada proses tersebut akan menghasilkan spent catalyst berupa Residual Catalytic Cracking (RCC) hal ini karena katalis tidak ikut bereaksi. $R C C$ ini dapat digunakan sebagai katalis dalam perengkahan limbah plastik menjadi bahan bakar cair (Maarif 2009; Istadi et al. 2011; Ermawati et al. 2016; Naimah et al. 2016). Cracking (perengkahan) merupakan suatu proses pemutusan senyawa kimia yang mempunyai rantai panjang ikatan $\mathrm{C}-\mathrm{C}$ dengan suhu tinggi.

Gas hasil samping proses pirolisis dikarakterisasi menggunakan alat GC dengan detektor TCD dan FID. Komposisi gas hasil pirolisis terdiri dari hidrogen, karbon monoksida, karbon dioksida, metana, etana, propana, butana, dan pentana (Kuncser et al. 2010). Pada penelitian ini digunakan limbah plastik PE karena tidak dapat didaur ulang dan didegradasi oleh lingkungan. Limbah plastik selain PE banyak didaur ulang untuk dijadikan produk baru. Penambahan katalis RCC dengan berbagai variabel diharapkan dapat diketahui karakteristik gas yang dihasilkan pada proses pirolisis limbah plastik PE.

Penelitian ini bertujuan untuk membandingkan karakteristik gas yang dihasilkan pada proses pirolisis limbah plastik $\mathrm{PE}$ dengan variabel konsentrasi menggunakan katalis $R C C$.

\section{BAHAN DAN METODE}

\section{Bahan}

Bahan yang dibutuhkan dalam penelitian ini adalah limbah plastik kresek (PE), katalis $R C C$ yang berasal dari limbah Pertamina, dan $\mathrm{CaCO}_{3}$. Adapun alat yang digunakan adalah crusher untuk mencacah limbah plastik, reaktor pirolisis yang telah dimodifikasi (Gambar 1) kapasitas $5 \mathrm{~kg}$ yang terdiri dari reaktor, kondensor, tangki air, dan tangki penampung produk, penampung gas dari plastik 500 L, flowmeter, gas sampler plastik dari polypropylene dan GC system merk Shimadzu 2014 yang terdiri dari TCD-FID.

\section{Metode}

Proses pirolisis menggunakan katalis $R C C$ seperti yang dilakukan oleh (Ermawati et al. 2016) dan (Naimah et al. 2016). Pada penelitian sebelumnya (Ermawati et al. 2016) telah membandingkan zeolit yang diaktivasi dan $R C C$ sebagai katalis proses pirolisis limbah plastik PE, didapatkan bahwa produk fase cair lebih tinggi dengan menggunakan katalis $R C C$. Katalis $R C C$ yang digunakan tidak divariasikan, sehingga pada penelitian ini dilakukan variabel RCC. Variabel konsentrasi katalis RCC yang dipakai adalah $7,5 \%$; $10 \%$; $12,5 \%$; $15 \%$; dan $17,5 \%$ terhadap bahan baku. Bahan baku limbah plastik PE sebesar $5 \mathrm{~kg}$ dan katalis dimasukkan ke fluidized bed reactor yang dilengkapi dengan pemanas (furnace) (Gambar 1). Suhu proses yang digunakan adalah $350^{\circ} \mathrm{C}$ sampai dengan $450{ }^{\circ} \mathrm{C}$. Selama proses konversi, plastik akan berubah dari fase padat menjadi fase cair dalam bentuk uap. Fase uap akan terbawa oleh gas untuk diproses lebih lanjut pada alat pendingin (condenser) dengan posisi miring untuk dipisahkan antara fraksi cair dan gas. 


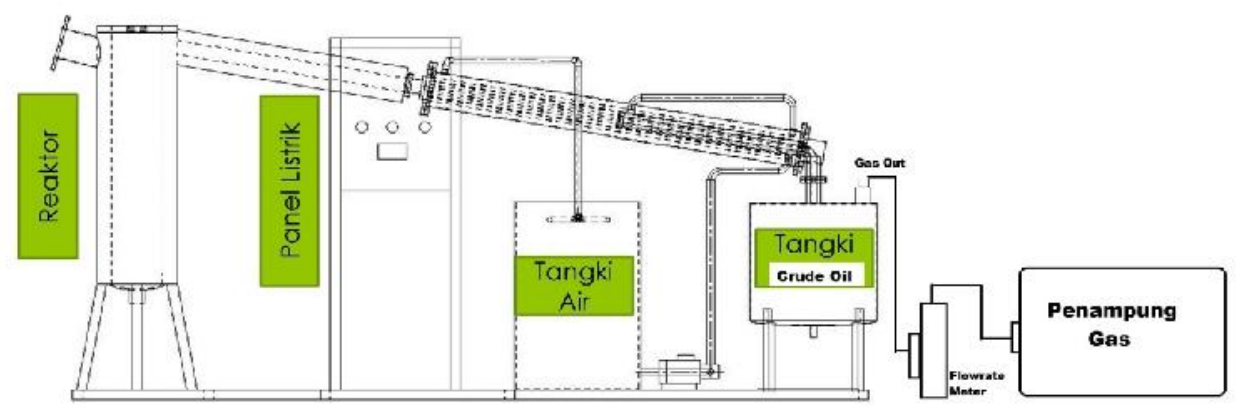

Gambar 1. Reaktor pirolisis (Ermawati et al. 2013)

Gas yang tidak terkondensasi akan tetap berwujud gas diukur flowrate-nya menggunakan flowmeter. Selanjutnya gas diambil menggunakan gas sampler untuk dikarakteristik menggunakan alat $G C$ system.

\section{HASIL DAN PEMBAHASAN}

Proses cracking pirolisis ditandai dengan keluarnya cairan yang ditampung pada tangki penampung. Cairan yang dihasilkan merupakan hasil dari proses kondensasi dari pemutusan rantai panjang plastik kresek $P E$ yang digunakan, sedangkan yang tidak terkondensasi akan tetap menjadi gas. Gas yang dihasilkan merupakan gas yang mengandung komponen hidrokarbon yang dapat digunakan sebagai sumber energi. Pada saat proses pirolisis berlangsung, dilakukan sampling gas untuk dianalisis komposisi dengan GC system.

Proses pirolisis menggunakan bahan baku plastik kresek PE menghasilkan komposisi gas oksigen, nitrogen, metana, karbon monoksida, karbon dioksida, etana, propana, butana, n-butana, pentana, n-pentana, dan n-heksana. Komposisi gas hasil pirolisis menggunakan katalis $R C C 7,5 \%$ dapat dilihat pada Gambar 2, sedangkan penggunaan katalis $10 \%$ dapat dilihat pada Gambar 3 .

Data pada Gambar 2 menunjukkan bahwa proses pirolisis menggunakan katalis 7,5\% menghasilkan metana dan propana paling dominan yaitu masing-masing sebesar $17,879 \%$ dan $17,507 \%$. Gas metana dan propana dapat digunakan sebagai bahan bakar. Tetapi pada proses tersebut menghasilkan gas $\mathrm{CO}_{2}$ sebesar $2,706 \%$. Gas $\mathrm{CO}_{2}$ yang terbentuk merupakan gas polutan dan diharapkan kadarnya kecil atau bahkan tidak ada di dalam bahan bakar. Pada penggunaan katalis RCC 10\% (Gambar 3) didapatkan konsentrasi propana yang tinggi yaitu masing-masing sebesar $24,096 \%$ dan kadar butana sebesar 11,661\%. Kadar CO dan $\mathrm{CO}_{2}$ pada penggunaan katalis $10 \%$ menurun menjadi $0 \%$ dan $0,193 \%$. Hal ini terjadi karena penambahan katalis mampu menghilangkan karbon monodioksida dan karbon dioksida. Komposisi gas menggunakan katalis 12,5\% dapat dilihat pada Gambar 4, sedangkan penggunaan katalis $15 \%$ dapat dilihat pada Gambar 5, dan penggunaan katalis $17,5 \%$ dapat dilihat pada Gambar 6 .

Pada penggunaan katalis 12,5 komponen utama yang dihasilkan adalah propana. Kadar propana yang dihasilkan adalah sebesar $27,266 \%$ dan n-butana sebesar 5,359\%, sedangkan pada penggunaan katalis $17,5 \%$ menghasilkan propana sebesar 10,709\% dan kadar n-butana sebesar 4,812\%. Kadar katalis propana pada penggunaan katalis $17,5 \%$ lebih rendah dibandingkan dengan penggunaan katalis $7,5 \%$; $10 \%$; dan 12,5\%; hal ini disebabkan kadar nitrogen yang tinggi yaitu $34,245 \%$. Adanya nitrogen pada gas hasil pirolisis salah satu pengotor dalam katalis $R C C$ adalah nitrogen (Sadeghbeigi 2012). Selain itu tingginya kadar nitrogen dipengaruhi oleh suhu pada proses pirolisis, merupakan indikasi adanya pengotor nitrogen tersebut berasal dari katalis $R C C$. Semakin tinggi suhu nitrogen yang terbentuk, semakin kecil hal ini sesuai dengan penelitian yang telah dilakukan Istadi et al. (2011) yang menggunakan bahan baku limbah PE dan katalis RCC. Nitrogen yang dihasilkan pada suhu $370{ }^{\circ} \mathrm{C}$ adalah sebesar $25 \%$, sedangkan pada suhu $455^{\circ} \mathrm{C}$ adalah $5,85 \%$. 

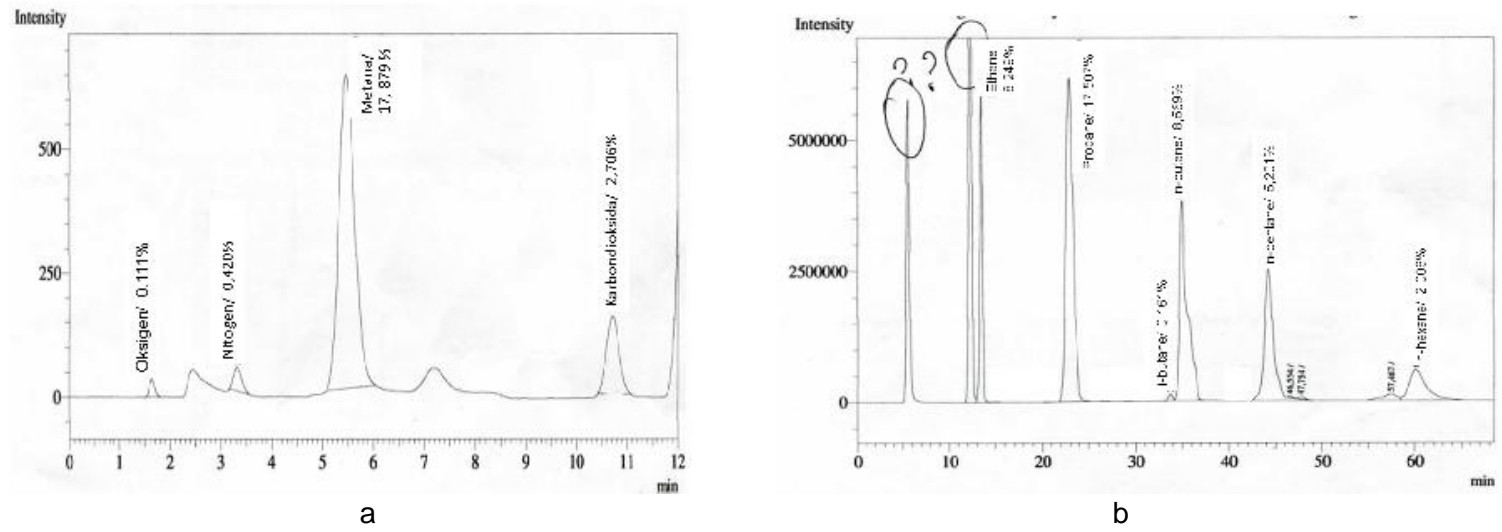

Gambar 2. Hasil analisis gas pirolisis limbah plastik dengan katalis 7,5\% : a) karakteristik gas oksigen, nitrogen, metana, dan karbon dioksida, b) karakteristik gas etana, propana, i-butana, n-butana, n-pentana, dan n-heksana

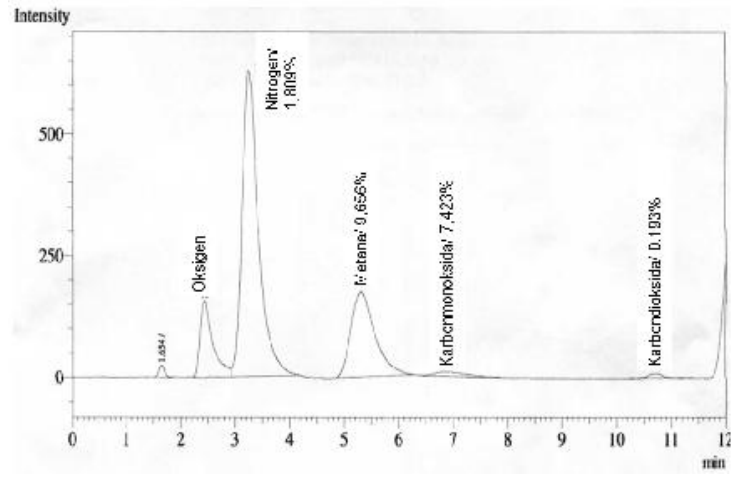

a

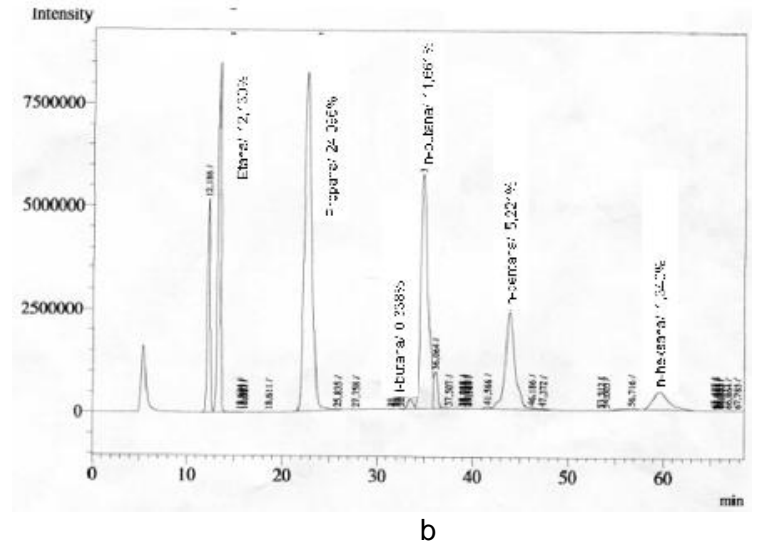

b

Gambar 3. Hasil analisis gas pirolisis limbah plastik dengan katalis 10\%: a) karakteristik gas oksigen, nitrogen, metana, karbon monoksida, dan karbon dioksida, b) karakteristik gas etana, propana, i-butana, n-butana, n-pentana, dan n-heksana

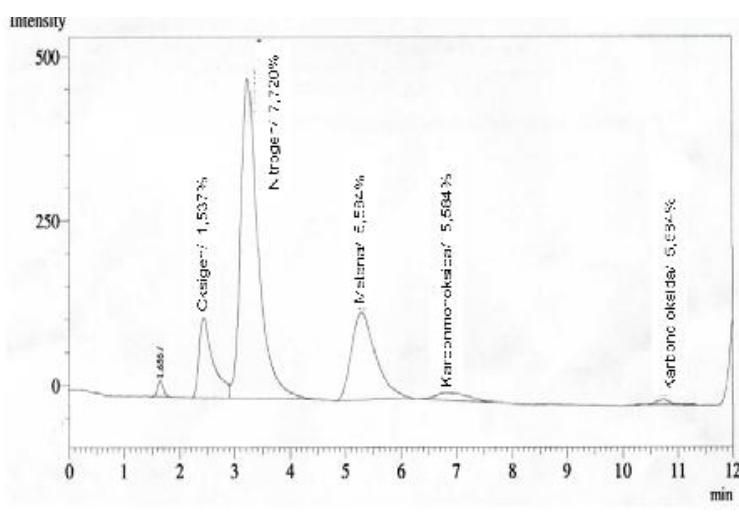

a

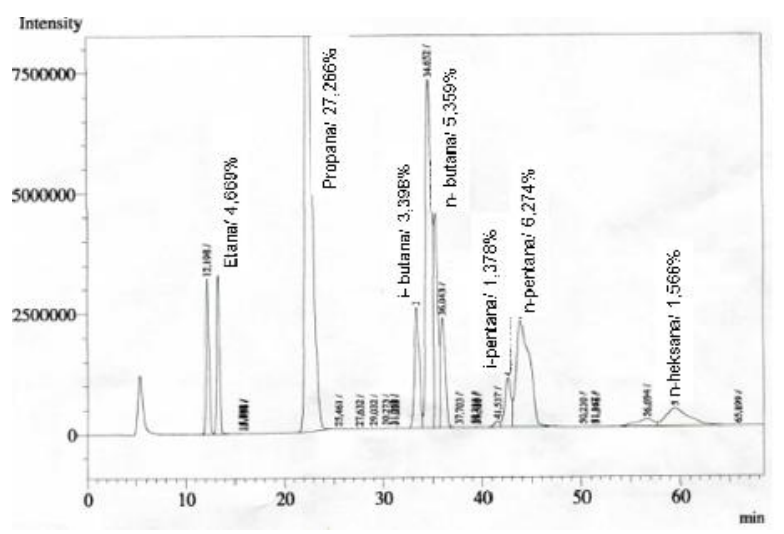

b

Gambar 4. Hasil analisis gas pirolisis limbah plastik dengan katalis $12,5 \%$ : a) karakteristik gas oksigen, nitrogen, metana, karbon monoksida, dan karbon dioksida, b) karakteristik gas etana, propana, i-butana, n-butana, n-pentana, dan n-heksana 


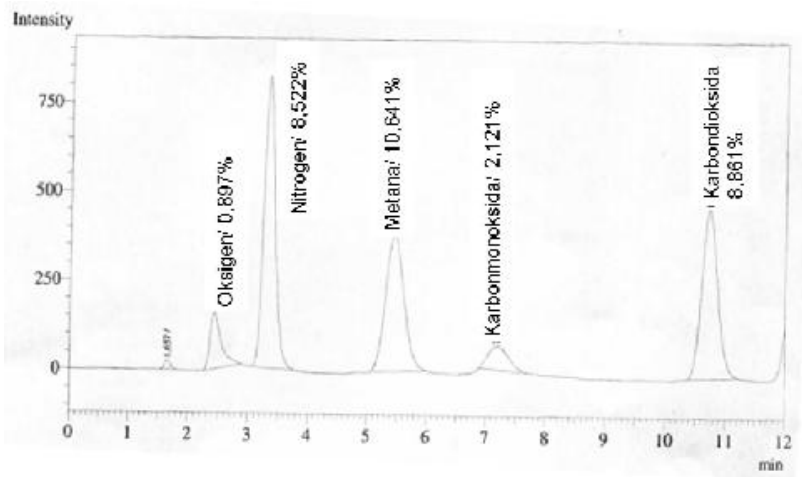

Gambar 5. Hasil analisis gas pirolisis limbah plastik dengan katalis 15\% (parameter gas oksigen, nitrogen, metana, karbon monoksida, dan karbondioksida)

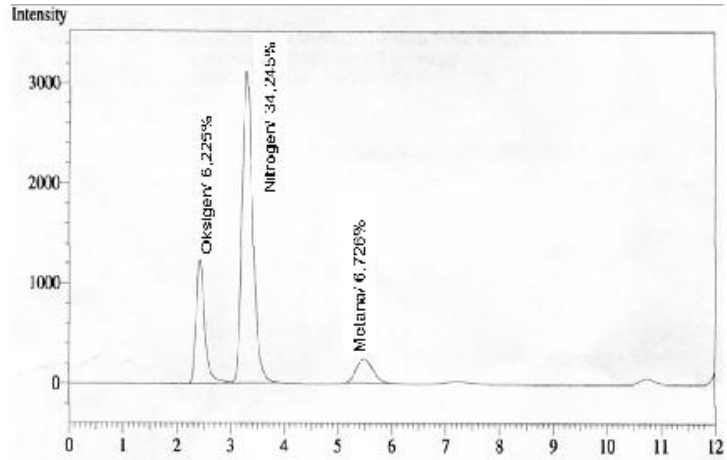

a

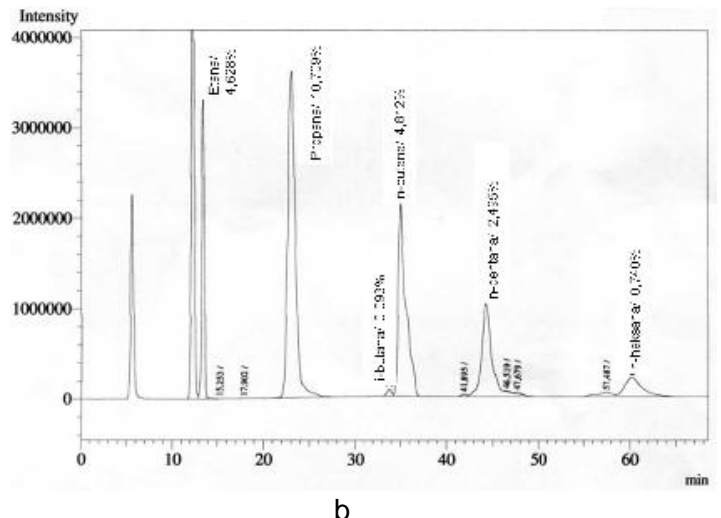

b

Gambar 6. Hasil analisis gas pirolisis limbah plastik dengan katalis 17,5\% : a) karakteristik gas oksigen, nitrogen, dan metana, b) karakteristik gas etana, propana, i-butana, n-butana, n-pentana, dan n-heksana

Kadar metana yang dihasilkan pada penggunaan $R C C 15 \%$ tinggi yaitu sebesar $10,641 \%$, sedangkan kadar gas $\mathrm{CO}$ dan $\mathrm{CO}_{2}$ sebesar $2,121 \%$ dan $8,861 \%$ lebih tinggi jika dibandingkan dengan penggunaan katalis 7,5\%; $10 \%$; $12,5 \%$; dan 17,5\%. Hal ini disebabkan senyawa PE mudah teroksidasi dengan adanya oksigen sehingga membentuk $\mathrm{CO}$ dan $\mathrm{CO}_{2}$, disamping itu juga penambahan katalis akan berpengaruh terhadap penambahan oksida (Sadeghbeigi 2012). Konsentrasi tertinggi campuran propana dan butana tertinggi didapatkan pada penggunaan katalis $10 \%$ yaitu sebesar 35,657\%. Propana dan butana merupakan komposisi utama pada bahan bakar LPG yaitu campuran propana dan butana harus minimum $97 \%$ dan kadar $\mathrm{C}_{2}$ maksimum $0,8 \%$ serta $\mathrm{C}_{5}$ maksimum diperbolehkan adalah 2,0\% (Direktur Jenderal Minyak dan Gas Bumi 2009). Gas hasil pirolisis menggunakan variabel katalis 7,5\%; 10\%; 12,5\%; 15\%; dan 17,5\% dengan kapasitas reaktor pirolisis sebesar $5 \mathrm{~kg}$. Istadi et al. (2011) telah melakukan penelitian terhadap komposisi gas dari limbah plastik HDPE menggunakan reaktor berkapasitas $0,9 \mathrm{~L}$ dan $5 \mathrm{~L}$ dengan jumlah sampel $20 \mathrm{~g}$ sampai dengan $30 \mathrm{~g}$ dan $70 \mathrm{~g}$ sampai dengan $150 \mathrm{~g}$.
Total propana dan butana pada gas hasil pirolisis menggunakan katalis 7,5\%; $10 \%$; $12,5 \%$; $15 \%$; dan $17,5 \%$ masih dibawah $97 \%$, selain itu kadar $\mathrm{C}_{2}$ (etana) masih diatas 0,8\% dan $\mathrm{C}_{5}$ (pentana) masih diatas 2,0\%. Kadar etana diatas batas maksimum dapat menyebabkan nyala kompor agak kemerahan. Gas yang dihasilkan dapat dimanfaatkan sebagai bahan pembuat LPG (Liquid Petroleum Gas) yang terdiri unsur karbon dan hidrogen merupakan senyawa hidokarbon dengan komponen utama $\mathrm{C}_{3}$ dan $\mathrm{H}_{4}$. Komposisi $L P G$ tersebut terdiri dari senyawa propana $\mathrm{C}_{3} \mathrm{H}_{8}$, butana $\mathrm{C}_{4} \mathrm{H}_{10}$, butena $\mathrm{C}_{4} \mathrm{H}_{8}$, dan sejumlah kecil etana $\mathrm{C}_{2} \mathrm{H}_{4}$ dan pentana $\mathrm{C}_{5} \mathrm{H}_{12}$ (Shukur et al. 2013).

Berdasarkan jenis komposisi tersebut menerangkan bahwa gas metana, propana, n-butana, dan etana merupakan gas yang paling dominan terbentuk. Gas metana merupakan bahan bakar gas yang dibutuhkan yang memiliki sifat tidak berbau, mudah terbakar, tidak toksik, dan tidak korosi. Gas metana banyak digunakan sebagai bahan bakar gas LNG (Liquid Natural Gas) dan CNG (Compress Natural Gas).

Flowrate gas hasil pirolisis diukur untuk mengetahui kecepatan gas yang terbentuk dan waktu proses yang dibutuhkan untuk setiap 
variasi jumlah katalis. Tabel 3 menerangkan perbandingan jumlah katalis terhadap waktu proses.

Setiap proses pirolisis dengan bahan baku plastik $4 \mathrm{~kg}$ mendapatkan gas hasil samping sebesar 500 L. Flowrate gas yang keluar dari proses tanpa menggunakan katalis sebesar 1,70 L/menit. Semakin banyak katalis yang digunakan, proses pirolisis akan semakin cepat. Namun pada pemakaian katalis sebanyak $17,5 \%$, kecepatan proses tidak mengalami peningkatan. Hal ini terjadi karena jumlah katalis yang ditambahkan sudah sebanding dengan bahan baku yang direngkah dari rantai hidrokarbon yang panjang menjadi rantai pendek. Penelitian selanjutnya diperlukan untuk meningkatkan campuran propana dan butana karena untuk digunakan sebagai LPG kedua campuran tersebut minimal $97 \%$ sesuai baku mutu yang ditetapkan oleh Dirjen Migas (Direktur Jenderal Minyak dan Gas Bumi 2009).

Tabel 3. Perbandingan jumlah katalis terhadap waktu proses

\begin{tabular}{ccc}
\hline $\begin{array}{c}\text { Jumlah katalis } \\
(\%)\end{array}$ & $\begin{array}{c}\text { Flowrate } \\
\text { (L/menit) }\end{array}$ & $\begin{array}{c}\text { Waktu } \\
\text { proses } \\
\text { (menit) }\end{array}$ \\
\hline 0 & 1,70 & 294 \\
7,5 & 2,10 & 238 \\
10 & 2,35 & 213 \\
12,5 & 2,57 & 195 \\
15 & 2,73 & 183 \\
17,5 & 2,73 & 183 \\
\hline
\end{tabular}

\section{KESIMPULAN}

Berdasarkan karakterisasi dan komposisi gas dari berbagai variabel katalis $R C C$ yang digunakan didapatkan konsentrasi optimum adalah dengan penambahan katalis $10 \%$ yang menghasilkan campuran propana dan butana yang lebih tinggi yaitu $35,757 \%$; ethana $12,13 \%$; dan pentana $5,221 \%$ dibandingkan dengan konsentrasi konsentrasi katalis yang lainnya $7,5 \%$; $12,5 \%$; $15 \%$; dan $17,5 \%$. Gas CO dan $\mathrm{CO}_{2}$ yang dihasilkan pada penggunaan katalis $7,5 \%$ sampai dengan $15 \%$ sangat rendah dibandingkan dengan penggunaan katalis 17,5\% yaitu sebesar $2,121 \%$ dan $8,861 \%$.

\section{UCAPAN TERIMA KASIH}

Penulis menyampaikan terima kasih kepada Balai Besar Kimia dan Kemasan yang telah memberikan dana untuk penelitian ini dan rekan-rekan selaku tim yang turut serta dalam penelitian ini. Penulis juga mengucapkan terima kasih kepada Dr. Rahyani Ermawati, atas saran dan bimbingan dalam menyelesaikan penulisan ini.

\section{DAFTAR PUSTAKA}

Ademiluyi, T, and T. A Adebayo. 2007. "Fuel Gases from Pyrolysis of Waste Polyethylene Sachets" 11 (2): 21-26.

Almeida, Débora, and Maria de Fátima Marque. 2015. "Thermal and Catalytic Pyrolysis of Polyethylene Plastic Waste in Semi." Polimeros $26 \quad$ (1): 1-8. doi:http://dx.doi.org/10.1590/01041428.2100 .

Ćwik, Agnieszka. 2014. "Fuel from Waste Catalytic Degradation of Plastic Waste to Liquid Fuels."

Direktur Jenderal Minyak dan Gas Bumi, Depatemen Energi dan sumber Daya Mineral. 2009. "Keputusan Direktur Jenderal Minyak Dan Gas Bumi Tentang Standar Dan Mutu (Spesifikasi Bahan Bakar Gas Jenis Liquefied Petroleum Gas (LPG) Yang Dipasarkan Di Dalam Negeri." http://hubdat.dephub.go.id/keputusandirjen/384-tahun-1996.

Ermawati, R, N Bumiarto, I Rumondang, E Oktarina, and S Naimah. 2016. "Pengaruh Residual Catalytic Cracking (RCC) Dan ZeolitTerhadap Kualitas Crude Oil Hasil Pirolisis Limbah." Jurnal Kimia Kemasan 38 (1): 47-54.

Hartulistiyoso, E, F.A.P.A.G. Sigiro, and M Yulianto. 2015. "Temperature Distribution of the Plastics Pyrolysis Process to Produce Fuel at 450oC." Procedia Environmental Sciences 28 (SustaiN 2014): 234-41. doi:10.1016/j.proenv.2015.07.030.

Istadi, L Buchori, and Suherman. 2011. "Platic Waste Conversion to Liquid Fuels Over Modified-Residual Catalytic Cracking Catalysts: Modeling and Optimization Using Hybrid Artificial Neural Network - Genetic." Reaktor 13 (3): 131-39.

Kuncser, R, M Paraschiv, M Tazerout, and J Bellettre. 2010. "Liquid Fuel Recovery Through Pyrolysis of Polyethylene Waste." Environmental Engineering and Management Journal 9 (10): 1371-74.

Kyaw, K.T, C Su, and S Hmwe. 2015. "Effect of Various Catalysts on Fuel Oil Pyrolysis Process of Mixed Plastic Wastes." International Journal of Advances in Engineering \& Technology 8 (5): 794802.

Maarif, H. 2009. "Reaksi Kompetisi Antara Perengkahan Dan Polimerisasi Tir Karet Dari Ban Bekas Dengan Katalis Mo-Ni/Zeolit Y." Universitas Sebelas Maret Surakarta.

Naimah, S, S. A Aviandharie, and N.N Aidha. 2016. "Karakteristik Pelarut Dan Solar 
Hasil Proses Pirolisis Limbah Plastik Polietilen." Jurnal Kimia Dan Kemasan 38

109-14. doi:http://dx.doi.org/10.24817/jkk.v38i2. 2499.

Patni, N, P Shah, S Agarwal, and P Singhal. 2013. "Alternate Strategies for Conversion of Waste Plastic to Fuels." ISRN Renewable Energy 2013: 1-7. doi:10.1155/2013/902053.

Sadeghbeigi, R. 2012. Fluid Catalytic Cracking Handbook. Third edit. United States: Elsivier.

Sharma, B. K., B. R. Moser, K.E. Vermillion, K. M. Doll, and N. Rajagopalan. 2014. "Production, Characterization and Fuel Properties of Alternative Diesel Fuel from Pyrolysis of Waste Plastic Grocery Bags." Fuel Processing
Technology 122. Elsevier B.V.: 79-90. doi:10.1016/j.fuproc.2014.01.019.

Shukur, M F, Y M Yusof, S M M Zawawi, H a Illias, and M F Z Kadir. 2013. "Conductivity and Transport Studies of Plasticized Chitosan-Based Proton Conducting Biopolymer Electrolytes." Physica Scripta T157: 14050. doi:10.1088/00318949/2013/T157/014050.

Syamsiro, M, H Saptoadi, T Norsujianto, P Noviasri, S Cheng, Z Alimuddin, and $\mathrm{K}$ Yoshikawa. 2014. "Fuel Oil Production from Municipal Plastic Wastes in Sequential Pyrolysis and Catalytic Reforming Reactors." Energy Procedia 47. Elsevier B.V.: 180-88. doi:10.1016/j.egypro.2014.01.212. 
